\begin{tabular}{cc|c}
\hline Tar. Bil. Der. & Journal of Agricultural Sciences \\
& $\begin{array}{c}\text { Dergi web sayfası: } \\
\text { www.agri.ankara.edu.tr/dergi }\end{array}$ & Journal homepage: \\
& www.agri.ankara.edu.tr/journal
\end{tabular}

\title{
Effects of Sowing Date, Cultivar and Chitosan on Quality and Quantity of Rapeseed (Brassica napus L.) Oil
}

\author{
Banafsheh Beheshti MONFARED ${ }^{\text {a }}$, Ghorban NOORMOHAMADI ${ }^{\text {** }}$, Amir Hossein Shirani RAD ${ }^{\mathrm{b}}$, Eslam \\ Majidi HERVAN ${ }^{a}$ \\ ${ }^{a}$ Department of Horticultural Science and Agronomy, Science and Research Branch, Islamic Azad University, Tehran, IRAN \\ ${ }^{b_{S e e d}}$ and Plant Improvement Institute, AREEO, Karaj, IRAN
}

\section{ARTICLE INFO}

Research Article

Corresponding Author: Ghorban NOORMOHAMADI, E-mail: ghnourmohamadi@gmail.com, Tel: +98 (21) 44865154

Received: 20 August 2018, Received in Revised Form: 19 October 2018, Accepted: 04 November 2018

\begin{abstract}
The effects of cultivars and sowing date along with chitosan application on oil yield, yield components and fatty acids of rapeseed (Brassica napus L.), were investigated. Five cultivars (RGS003, Sarigol, Zafar, Dalgan, and Julius) were sown in three sowing dates (October 7, 17, and 27), for two years (2014-2015 and 2015-2016). A factorial split-plot experiment was conducted in a complete randomized blocks design with three replications, where the sowing dates and the two levels of chitosan ( 0 \{control $\}$ and $0.2 \%$ concentrations) were allotted to main plots and the cultivars were allotted to subplots. ANOVA revealed a significant $(\mathrm{P}<0.01)$ effects of the three studied factors on studied characters. Sarigol cultivar had the highest amount of seed yield (4447 $\left.\mathrm{kg} \mathrm{ha}^{-1}\right)$, seed oil (45.51\%) and biological yield (15672 kg ha-1). These characters had the highest values in the first sowing date. Application of chitosan solution increased the amount of seed yield from 3916 to $4233\left(\mathrm{~kg} \mathrm{ha}^{-1}\right)$, seed oil from 44.83 to $45.24 \%$ and biological yield from 13628 to $14797\left(\mathrm{~kg} \mathrm{ha}^{-1}\right)$. Delayed sowing dates, increased the linolenic and erucic acids and decreased the palmitic, oleic, and linoleic acids. The results of the present study indicated that early sowing date and chitosan application had positive effects on the quantity and quality of rapeseed oil. Cluster analysis divided the cultivars into two main clusters. The PCA revealed that the three first PC confirmed about $96 \%$ of the total variance among the studied cultivars.
\end{abstract}

Keywords: Rapeseed (Brassica napus L.); Seed oil; Biological yield; Year

(C) Ankara Üniversitesi Ziraat Fakültesi

\section{Introduction}

Rapeseed or oilseed rape (Brassica napus L.) is one of the most important oilseeds with $40-44 \%$ oil and it is the world's third annual edible oil after soybean (Glycine max Merril.) and oil palm (Elaeis guineensis Jacq.) (Enjalbert et al 2013). Also, the oil of the plant is currently considered as the best oil in human nutrition with $61 \%$ oleic acid, $20 \%$ linoleic acid (Spasibionek et al 2003).

Oil yield and glucosinolate accumulation in canola are inheritable, however, they are affects by environmental factors, too (Fieldsend et al 1991; Azizi et al 2006). Early and late sowing dates causes the plant to be exposed to undesirable environmental conditions. The determination of the best sowing 
date plays an important role in the confirmation of plant growth stages to desirable environmental conditions, resulting in maximum quality and quantity yield (Siadat \& Hemayati 2009). The sowing date is the most effective treatment on the physiological and physiological characteristics of the crop (Khayat 2007). Optimum sowing date cause in the better seedling establishment and improved cold tolerance (Sultan \& Angadi 2016). However delay sowing date cause decreasing in plant height and seed yield (Alisial et al 2005). The early and late sowing date of this plant causes the plant to face a variety of stresses during its growth. The chitosan is a useful natural polymer that produced by alkaline $\mathrm{N}$-deacetylation of chitin. It is a component of the cell walls of some algae, fungi, and insects. The chitosan can be sprayed on plant aerial parts to induce the accumulation of bioactive secondary metabolites (Lei et al 2011; Yin et al 2011). Spraying plants with chitosan compensated to some extent for the negative impact of drought stress on some main characters. Reduction of the negative impact of drought on some characters by foliar application of chitosan has been reported in different plants (Dzung et al 2011; Mahdavi et al 2011). Bittelli et al (2001) reported that it reduced plant transpiration in pepper (Capsicum sp. L.), resulting in $26-43 \%$ reduction in water use without a reduction in dry matter yield. With increased levels of chitosan and drought stress, the amount of oil of Thymus (Thymus daenensis Celak.) increased (Bistgani et al 2017). The chitosan is used to cover seeds, leaves, and fruits (Devlieghere et al 2004). Studies on the effect of sowing time and application of the chitosan on quality and quantity of rapeseed oil using different cultivars are limited in number. Therefore, the aim of this study was to determine the effects of three sowing times and chitosan on some traits in rapeseed cultivars.

\section{Material and Methods}

\subsection{Experiment conditions}

The study was conducted at the Karaj Seed and Plant Improvement Research Institute, Karaj, Iran $\left(35^{\circ} 49^{\prime} \mathrm{N}, 50^{\circ} 59^{\prime} \mathrm{E}\right.$; altitude of $1321 \mathrm{~m}$ asl) during the 2014-2015 and 2015-2016. This area has average annual rainfall and temperature of $354 \mathrm{~mm}$ and 14.2 ${ }^{\circ} \mathrm{C}$, respectively. The soil of the experimental was a loam clay, with montmorllionite clay mineral, low in nitrogen $(0.06-0.09 \%)$, with a $\mathrm{Ec}=0.66 \mathrm{dS} \mathrm{m}^{-1}$ and $\mathrm{pH}$ of 7.2-7.9 (Table 1). The experiment was organized in a randomized complete block design, with factorial split plot arrangement, with three replications. There were three factors including (5) cultivars of rapeseed (RGS003, Sarigol, Zafar, Dalgan and Julius), (3) sowing dates (October 7, 17

Table 1- The result of soil analysis

\begin{tabular}{|c|c|c|c|c|}
\hline \multirow[b]{2}{*}{ Parameter } & \multicolumn{2}{|c|}{$2014-2015$} & \multicolumn{2}{|c|}{$2015-2016$} \\
\hline & $\begin{array}{r}\text { Depth } \\
(0-30 \mathrm{~cm})\end{array}$ & $\begin{array}{r}\text { Depth } \\
(30-60 \mathrm{~cm})\end{array}$ & $\begin{array}{r}\text { Depth } \\
(0-30 \mathrm{~cm})\end{array}$ & $\begin{array}{r}\text { Depth } \\
(30-60 \mathrm{~cm})\end{array}$ \\
\hline Electrical conductivity $\left(\mathrm{dS} \mathrm{m}^{-1}\right)$ & 1.45 & 1.24 & 1.33 & 1.15 \\
\hline $\mathrm{pH}$ & 7.90 & 7.20 & 7.80 & 7.40 \\
\hline Total neutralizing value (\%) & 8.56 & 6.68 & 8.25 & 8.46 \\
\hline Moisture content $(\%)$ & 36.00 & 38.00 & 35.00 & 37.00 \\
\hline Organic carbon $(\%)$ & 0.91 & 0.99 & 0.83 & 0.96 \\
\hline Total N (\%) & 0.09 & 0.07 & 0.08 & 0.06 \\
\hline Available P $\left(\mathrm{mg} \mathrm{kh}^{-1}\right)$ & 14.70 & 15.80 & 14.20 & 15.30 \\
\hline Available K $\left(\mathrm{mg} \mathrm{kh}^{-1}\right)$ & 197.00 & 155.00 & 165.00 & 148.00 \\
\hline Clay $(\%)$ & 28.00 & 25.00 & 29.00 & 27.00 \\
\hline Silt (\%) & 47.00 & 49.00 & 45.00 & 46.00 \\
\hline Sand $(\%)$ & 25.00 & 26.00 & 26.00 & 27.00 \\
\hline Soil texture & Clay loam & Clay loam & Clay loam & Clay loam \\
\hline
\end{tabular}

Tarım Bilimleri Dergisi - Journal of Agricultural Sciences 25 (2019) 508-517 
and 27) and (2) levels of chitosan (0: control and $0.2 \%$ ). The sowing dates and chitosan were allotted to main plots. However the cultivars were allotted to subplots. A solution of chitosan $(0.2 \%)$ was sprayed at budding time. Soil samples were collected at the depth of $0-30 \mathrm{~cm}$ and $30-60 \mathrm{~cm}$, before seed sowing. The soil physicochemical properties were presented in Table 1. According to the soil analysis, $150 \mathrm{~kg} \mathrm{ha}^{-1}$ of ammonium phosphate and potassium sulphate before sowing date and $350 \mathrm{~kg} \mathrm{ha}^{-1}$ urea at (3) different times $\left(100,150\right.$ and $100 \mathrm{~kg} \mathrm{ha}^{-1}$ at sowing time, stem elongation and flowering stage, respectively), were applied.

Each experiment plot consisted of 6 lines 6 meters with lines of $60 \mathrm{~cm}$ and plant spacing on the $4 \mathrm{~cm}$ line, as well as two lateral lines as margins and its four middle lines were used to determine all phonological stages of the plant and various traits. Irrigation and disease control measures were done as per requirement. At full maturity ten randomly selected sample plants were collected separately from each plot.

\subsection{The measured characters}

In the maturity stage the following characters were measured, seed yield, number of pods per plant, number of seeds per pod, 1000-seed weight, biological yield, and seed oil yield. The oil content was extracted by Soxhlet method (Joshi et al 1998). Also, seed glucosinolate content and fatty acids in the oilseeds were measured using with a highperformance liquid chromatography device (HPLC; Unicam 4600, England) (Yang et al 2009).

\subsection{Data analysis}

In order to verify the homogeneity of error variance of combined analysis, Bartlett's $\chi^{2}$ test was used. Since the data of the two years had homogeneous variances, the combined analysis was performed on the data. The data were analyzed using Statistical Analysis Software (V. 9.1; SAS Institute, Cary, $\mathrm{NC})$. In addition, the mean values were compared by using the LSD test (Steel \&Torrie 1980). Cluster analysis was conducted to distinguish among the five cultivars based on the arithmetic mean (UPGMA) method. The cluster analysis was performed by SPSS software on Windows 20.0 (SPSS Inc., Chicago, IL).The principal component analysis (PCA) was conducted with MetaboAnalyst Software (v. 3.0) (Xia \& Wishart 2016).

\section{Results and Discussion}

\subsection{Analysis of variance}

The result of Bartlett's $\chi^{2}$ test for all characters showed that the data of the two years had homogeneous variances, therefore the combined analysis was performed on the data. Analysis of variance indicated that the effects of the cultivar, year, sowing date, and the chitosan were significant $(\mathrm{P}<0.01)$ in all studied characters (Table 2). Rad et al (2015) reported that all assessed traits in canola were significant by the different sowing dates. Siadat \& Hemayati (2009) described the variety factor had a significant effect on all rapeseed characters (except for single seed weight). The result revealed that interaction between sowing date and cultivar was significant $(\mathrm{P}<0.01)$ on all studied traits (except for palmitic and oleic acids). The factors interaction means that the sowing dates produced a differential effect on the response of cultivars for many traits. The similar significant interaction was found between sowing date and canola hybrid for seed yield and oil content (Lima et al 2017). The interaction between sowing date and chitosan was significant $(\mathrm{P}<0.05)$ only for a number of pods per plant. There was no any other significant interactions between the factors studied (Table 2).

\subsection{Quantity characters}

The highest number of pods per plant was observed on the first sowing date (October 7; Table 3). The delay in the sowing date from the first to the third had a $25.22 \%$ decrease in the number of pods per but $0.2 \%$ of chitosan increased the trait about $10 \%$ compared to the control. Sarigol and Julius cultivars had the highest (169.44) and lowest (140.18) mean values for this character, respectively. The delay in the cultivation time from September 12 to October 12 decreased the number of pods per plant and 


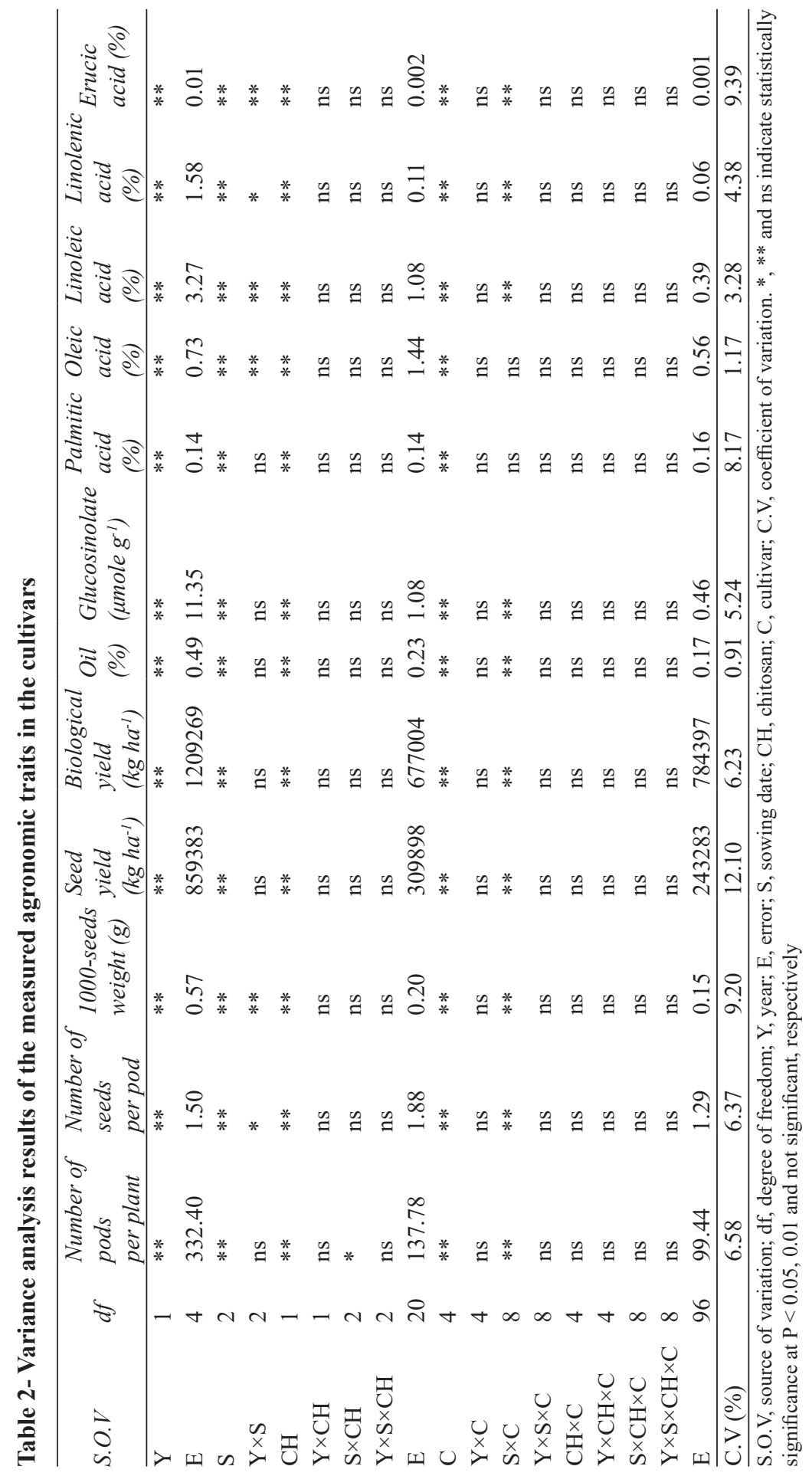

Tarım Bilimleri Dergisi - Journal of Agricultural Sciences 25 (2019) 508-517 
seed yield (Pasban-Easlam 2009). The interaction between the sowing date and the chitosan was significant $(\mathrm{P}<0.05)$ for this trait. The application of chitosan in $7^{\text {th }}$ October had the highest mean value for this character (221.2; Figure 1).

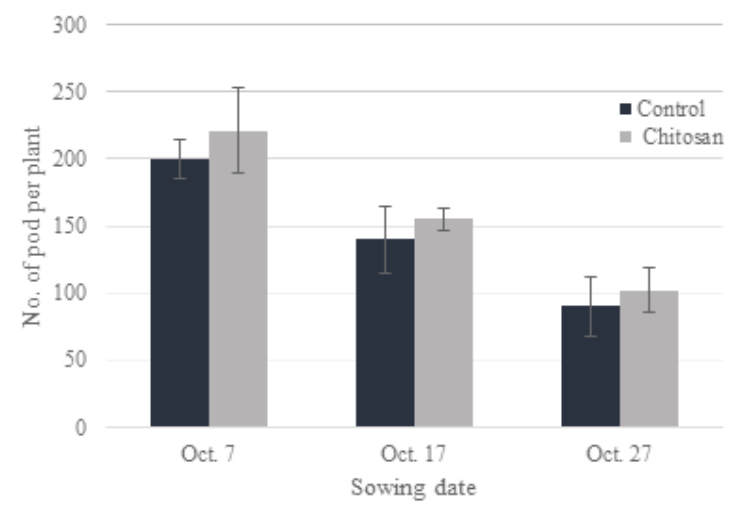

Figure 1- The interaction between the sowing date and the chitosan on a number of the pod ${ }^{-1}$ plant

Delay in sowing date from first to third reduced the number of seeds per pod about $33 \%$, but the $0.2 \%$ chitosan solution increased to $4.76 \%$ compared to the control (Table 3). The reduction of this character due to a delay in sowing date was reported in some studies (Fagheh 2000; Rahnama \& Bakhshandeh 2005). The interaction between cultivar and sowing date, and the interaction between Sarigol with the first sowing date and Julius with the third sowing date had the highest (22.88) and the lowest (13.45) mean value of a number of seed per pods (Table 4). The 1000-grain weight decreased from $5.26 \mathrm{~g}$ at the first sowing date to $3.18 \mathrm{~g}$ on the third sowing date (Table 3). In delay sowing date, the seed-filling period is associated with high temperature and the heat prevents grain seed filling (Robertson et al 2004; Fallah et al 2011). The application of $0.2 \%$ chitosan solution increased the character to $6.8 \%$ more than the control (Table 3). In the interaction between sowing date $\times$ cultivars, Sarigol in the first sowing date had the highest average $(5.71 \mathrm{~g})$ of this trait (Table 4).
The highest (5283 $\left.\mathrm{kg} \mathrm{ha}^{-1}\right)$ and the lowest (2844 $\mathrm{kg} \mathrm{ha}^{-1}$ ) grain yield were recorded on the first and third sowing dates, respectively. The chitosan solution $7.5 \%$ increased the seed yield than the control. RGS003 and Sarigol cultivars had more average for this character than the others cultivars (Table 3). When canola seeds were sown on $7^{\text {th }}$ and $27^{\text {th }}$ October, Sarigol and Julius cultivars showed the maximum and minimum mean value of seed yield, respectively (Table 4). In many studies, delay in sowing date caused seed yield reduction (Taylor \& Smith 1992; Johnson et al 2006; Siadata \& Hemayati 2009; Turhan et al 2011; Delkhosh et al 2012). Delay sowing date causes the maturity period to be exposed to high temperatures, which lead to reduced photosynthetic quantities and seed weight and ultimately reduced seed yield (Gan et al 2004; Rafiei et al 2011). Also, the delay sowing date cause reduces vegetative and reproductive growth times (Adamsem \& Coffelt 2005). As seen in Table 3 , delay in sowing date from the first $(18321 \mathrm{~kg}$ $\left.\mathrm{ha}^{-1}\right)$ to third $\left(10260 \mathrm{~kg} \mathrm{ha}^{-1}\right)$ reduced the biological yield about $44 \%$. The biological yield was increased by chitosan solution than the control treatment. Sarigol cultivar had the highest biological yield $\left(15672 \mathrm{~kg} \mathrm{ha}^{-1}\right)$. In the interaction between cultivar and sowing date, the maximum $\left(15533 \mathrm{~kg} \mathrm{ha}^{-1}\right)$ and minimum (12912 $\mathrm{kg} \mathrm{ha}^{-1}$ ) biological yield were observed in the interaction between Sarigoa with first sowing date and Julius with the third sowing date, respectively (Table 4). The weather and soil temperatures in delay sowing time are colder than early sowing as date, it causes reduce in the growth and development of dry matter in leaves and stems (Karakaya \& Altinok 2002). Sharif \& Keshta (2002) obtained the highest biological yield and dry matter of the plant in November than December.

The highest amount of seed oil (46.43\%) was observed at the first sowing date. Also, Sarigol cultivar had the maximum amount of the character (45.51\%) than other cultivars (Table 3). The interaction between sowing date and cultivar showed that the highest and lowest seed oil were in Sarigol with first sowing date and Julius with third sowing date interactions, respectively (Table 4). Delay 

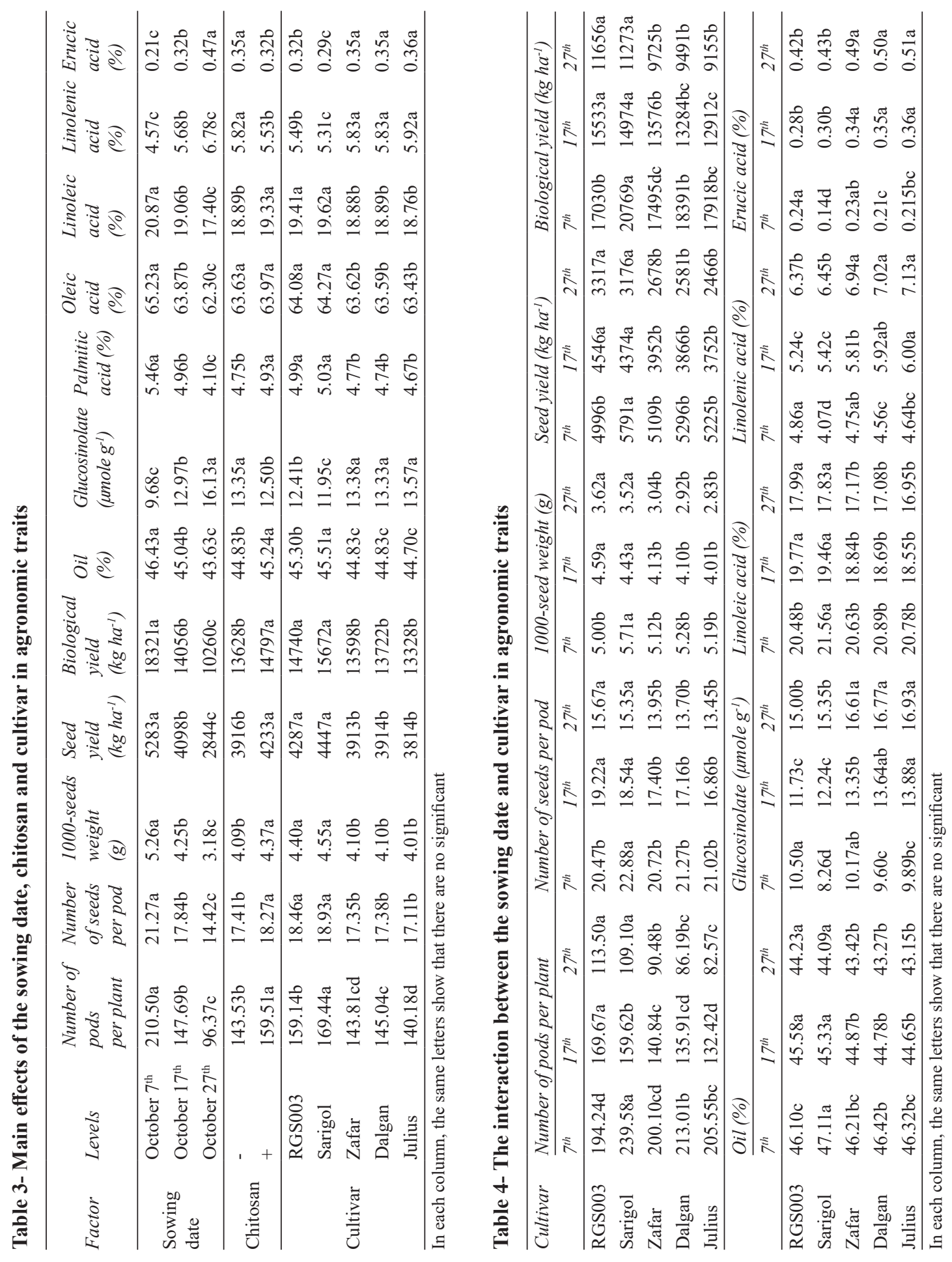

Tarım Bilimleri Dergisi - Journal of Agricultural Sciences 25 (2019) 508-517 
sowing date typically reduces the amount of canola seed oil (Hocking \& Stapper 2001). Temperature change during the filling stage can reduce the oil yield. The delay on sowing date causes flowering period falls in May-June when evaporation and transpiration reach high values caused the crop to confront water stress (Yau 2007). During the flowering period, rapeseed is susceptible to drought stress, however, the cultivars were found to possess varying sensitivity. Water stress decreased the seed yield of the crop, during the flowering stage (Bitarafan \& Shirani-Rad 2012).

\subsection{Fatty acid compositions and glucosinolate}

As seen in Table 3, the highest range of fatty acid value in the cultivars, was oleic acid (63.43$64.27 \%)$, and it was followed by linoleic acid (18.76-19.62\%), Linolenic acid (5.31-5.92\%), palmitic acid (4.67-5.03\%) and erucic acid (0.29$0.36 \%$ ). According to review literature, the amount of fatty acid compositions in canola oil is as follows: palmitic acid 2-6\%, oleic acid, 55-75\%, linoleic acid 10-24\%, linolenic acid 8-15\%, and erucic acid $<1 \%$ (Naseri 1991; Shariati \& Ghazi Shahinzadeh 2000; Azizi et al 2006). The effects of sowing date and chitosan were significant for all fatty acids measured. Delay in sowing dates causes to increase of linolenic and erucic acids and a decrease of oleic, linoleic, and palmitic acids (Table 3). Sowing time significantly affected on oleic and linoleic acids and the mean values of them decreased as sowing times were delayed (Turhan et al 2011). The application of $0.2 \%$ of chitosan solution cause to increase of oleic, linoleic, and palmitic acids and a decrease of linolenic and erucic acids. The highest (19.62\%) and lowest (18.76\%) oleic and linoleic acids were found in Sarigol and Julius, respectively (Table 3). As known as oleic and linoleic acids are the most important components of unsaturated fatty acids, which are important in terms of nutrition (Weber et al 2008). On the other hand, the quality of seed oil is mainly determined by oleic and linoleic acids contents (Ul-Hassan et al 2005). However linoleic acid is not synthesized in the body and must be supplied by diet (Naseri 1991; Dastpak 2001).
Sarigol and Julius cultivars had the highest (5.03\%) and lowest $(4.67 \%)$ average of palmitic acid (Table 3 ). Gecgel et al (2007) showed that the level of palmitic and oleic acids decreased when oil synthesis happened in hot weather. The result indicated that delayed sowing from $7^{\text {th }}$ to $27^{\text {th }}$ October increased the percentage of linoleic and erucic acids. The chitosan solution reduced both of these two harmful fatty acids than control treatment. Sarigol and Julius cultivars had the lowest and highest percentages of the two acids, respectively (Table 3 ). The interaction of the treatments showed that the lowest percentage of linolenic and erucic acids were recorded in Sarigol cultivar in the first sowing date (Table 4). These two fatty acids are very harmful to human health, and cultivars without these fatty acids have a high nutritional value (Dastpak 2001).

The result of this study showed delayed sowing date had a negative effect on the oil quality. It should be noted that the increase in temperature during seed formation changes the amount of fatty acids in seeds and affects the quantity and quality of seed oil (Ul-Hassan et al 2005). The three studied factors had effects on glucosinolate content. Sarigol and Julius cultivars had the lowest and highest glucosinolate content, respectively (Table 3 ). The interaction between sowing date and cultivar showed that Sarigol and Julius cultivars had the lowest and highest glucosinolate content at the first and third sowing dates, respectively (Table 4). Fieldsend et al (1991) showed that glucosinolate accumulation in canola seed is inherited, but also affects by environmental factors (Jan et al 2002; Grant et al 2003). Glucosinolate component is considered toxic to human and unfavorable for animal feed and egg production, however, its play an important role in plant's defense mechanism against pests (Kozlowska et al 1990). Early sowing date and application of the chitosan had a positive affected to reduce of this component. Sulisbury et al (1987) reported that an increase in glucosinolate reduces the quality and nutritional value of canola meal. The result of the present study showed that early sowing date and application of chitosan were useful to obtained high seed oil quality. 


\subsection{Cluster and PC analyses}

All measured characters were used to dendrogram generated, and the cluster analysis classified for the five rapeseed cultivars into two main clusters (Figure 2). Three cultivars including Zafar, Dalgan, and Julius were in the first cluster. The cultivars of this group had high values of linolenic acid, erucic acid, and glucosinolate than the second group. However, for the valuable fatty acids, the first group had lower values than the second group. The result indicated that the quality and quantity of the cultivars in the first cluster were more than the second cluster. The second group consist of two other cultivars (RGS003 and Sarigol cultivars). These cultivars had high levels of grain and oil yields and oleic and linoleic acids, indicated that the cultivars are suitable to cultivate in the area. The PCA revealed that the three first PC confirmed about $96 \%$ of the total variance among the five cultivars (Figure 3). The measured characters correlated substantially with the first component (PC1); therefore, it was named "Genotype". About $78 \%$ of the total variance among the cultivars was affected by different genotype, because the cultivars were cultivated in the same condition, so their variation due to genetic factors. The second and third components confirmed about 12.2 and $5.52 \%$ of the total variance among the cultivars, respectively. The three plots revealed

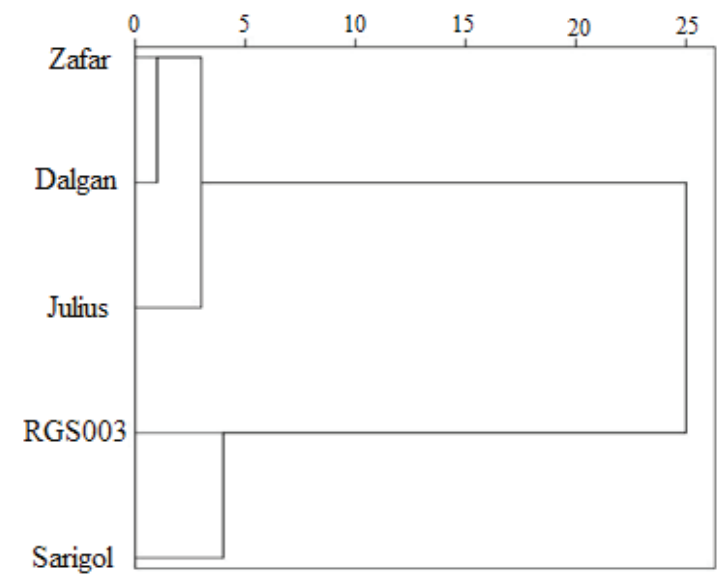

Figure 2- Dendrogram generated based on traits measured using the UPGMA method that the results of the cultivars were in agreement with the results of the cluster analysis (Figure 3). In both of them, the cultivars were divided in to main groups.

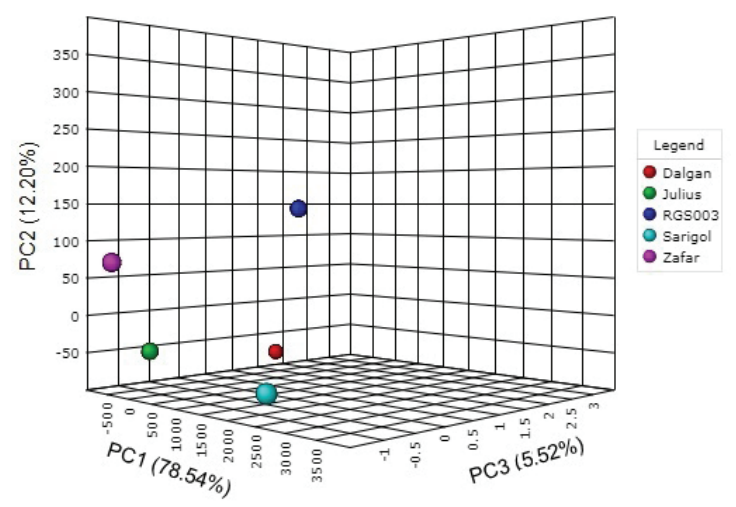

Figure 3- Three plots derived from the principal component analysis

\section{Conclusions}

The results of the study showed that the rapeseed cultivars responded differently to the sowing dates. Therefore, choosing a suitable sowing date is essential depending upon growing conditions and cultivar. The amount of three beneficial fatty acids including palmitic, linoleic, and oleic acids decreased due to delayed sowing date. Application of $0.2 \%$ of chitosan solution increased these three useful fatty acid and decreased harmful fatty acids including erucic and linolenic acids. The result of the present study showed that early sowing date and application of chitosan had a positive effect on the quality and quantity oil yield of the plant. According to the result, it can be suggested that the most appropriate sowing time to obtain a high quantity and quality of rapeseed oil, is early of October and application of chitosan and Sarigol cultivar as a way to increase canola yield. In the end, the determination of sowing date and choosing a suitable cultivar for each region are very important to obtain high quality and quantity of rapeseed oil. 


\section{References}

Adamsem F J \& Coffelt T (2005). Planting date effects on flowering, seed yield and oil content of rape and crambe cultivars. Industrial Crops and Products 21(3): 293-307

Alisial M, Arian M A, Khanzada S, Nagvi M H, Lemardahat M \& Nizamani N A (2005). Yield and quality parameters of wheat genotypes as affected by sowing date and high-temperature stress. Pakistan Journal of Botany 3: 576-584

Azizi M, Soltani A \& Kharri-Khorasani S (2006). Canola, Physiology, Agriculture, Behavioral and Biotechnology (Translation). Mashhad University Publications, pp. 230

Bistgani Z E, Siadat S A, Bakhshandeh A, Pirbalouti A G \& Hashemi M (2017). Interactive effects of drought stress and chitosan application on physiological characteristics and essential oil yield of Thymus daenensis Celak. The Crop Journal 5(5): 407-415

Bitarafan Z \& Shirani Rad A H (2012). Water stress effect on spring rapeseed cultivars yield and yield components in winter planting. International Journal of the Physical Sciences, 7(19): 2755-2767

Bittelli M, Flury M, Campbell G S \& Nichols E J (2001). Reduction of transpiration through foliar application of chitosan. Agricultural and Forest Meteorology 107(3): 167-175

Dastpak A (2001). Determination of chemistry and chemotaxonomy of several cultivars (Cucurbita). Master's thesis, Faculty of Science, Urmia University, pp 164

Delkhosh B, Shirani Rad A \& Mousavi G (2012). Drought stress and sowing date effects on yield and some grain traits of rapeseed cultivars. Advances in Environmental Biology 6(1): 49-55

Devlieghere F, Vermeulen A \& Debevere J (2004). Chitosan: antimicrobial activity, interactions with food components and applicability as a coating on fruit and vegetables. Food Microbiology 21: 703-711

Dzung N A, Khanh V T P \& Dzung T T (2011). Research on the impact of chitosan oligomers on biophysical characteristics, growth, development and drought resistance of coffee. Carbohydrate Polymers 84(2): 751-755

Enjalbert J N, Zheng S, Johnson J, Mullen L, Byrne P F \& McKay J K (2013). Brassicaceae germplasm diversity for agronomic and seed quality traits under drought stress. Industrial Crops and Products 47: 176-185

Fagheh P (2000). Review performance, yield components, growth and physiological parameters of rapeseed cultivars Dezful area. M.Sc. The thesis of agriculture, Islamic Azad University of Dezful, pp. 117

Fallah M H, Heki A R, Yadavi M, Movahhedi D \& Balouchi H R (2011). Evaluation of oil, protein and grain yield of canola cultivars in different planting date in Yasouj region. Electronic Journal of Crop Production 4(2): 207-222

Fieldsend J K, Murray F E, Bilsborrow P E, Milford G F J \& Evans E J (1991). Glucosinolate accumulation during seed development in winter-sown oilseed rape. pp. 686-694

Gan Y, Angadi S V, Cutforth H, Potts D, Angadi V V \& Mc Donald C L (2004). Canola and mustard response to short periods of temperature and water stress at different developmental stages. Canadian Journal of Plant Science 84(3): 697-704

Gecgel U, Demirci M, Esendal E \& Tasan M (2007). The fatty acid composition of the oil from developing seeds of different cultivars of safflower (Carthamus tinctorius L.). Journal of the American Oil Chemists' Society 84: 47-54

Grant C A, Clayton G W \& Johnston A M (2003). Sulfur fertilizer and tillage effects on canola seed quality in the Black soil zone of western Canada. Canadian Journal of Plant Science 83: 745-758

Hocking P J \& Stapper M (2001). Effect of sowing time and nitrogen fertilizer on canola and wheat. I. Dry matter production grain yield and yield components. Australian Journal of Agricultural Research 52: 623-634

Jan A, Khan N, Khan I A \& Khattak B (2002). The chemical composition of canola as affected by nitrogen and sulfur. Asian Journal of Plant Science 1: 519-521

Johnson B L, McKay K R, Schneiter A A, Hanson B K \& Schatz B G (2006). Influence of planting date on canola and crambe production. Journal of Production Agriculture 8: 594-599

Joshi N L, Mali P C \& Sexena A (1998). Effect of nitrogen and sulfur application on yield and fatty acid composition of mustard (Brassica juncea L.). Oil Journal of Agronomy \& Crop Science 180: 59-63

Karakaya A \& Altinok S (2002). Forage yield and quality of different turnip cultivars grown as main and second crop under Ankara conditions. Turkish Journal of Field Crops 7(2): 67-72

Khayat M (2007). The curve of growth, yield and yield components of rapeseed promising genotypes on different sowing conditions Khuzestan (Ahwaz). M.Sc. The thesis of Agriculture, Islamic Azad University, Science and Research Khuzestan Branch, pp. 250 
Kozlowska H, Naczk M, Shahidi F \& Zadernowski R (1990). Phenolic acids and tannins in rapeseed and canola. In: Canola and Rapeseed: Production, Chemistry, Nutrition and Processing Technology. Eds. Shahidi F. New York, Van Nostrand Reinhold. pp. 193-210

Lei C, Ma D, Pu G, Qiu X, Du Z, Wang H, Li G, Ye H \& Liu B (2011). Foliar application of chitosan activates artemisinin biosynthesis in Artemisia annua L. Industrial Crops and Products 33(1): 176-182

Lima L H, Braccini A L, Scapim C A, Piccinin G \& Ponce R M (2017). Adaptability and stability of canola hybrids in different sowing dates. Revista Ciência Agronômica 48(2): 374-380

Mahdavi B, Modarres Sanavy S A, Aghaalikhani M, Sharifi M \& Dolatabadian A (2011). Chitosan improves osmotic potential tolerance in safflower (Carthamus tinctorius L.) seedlings. Journal of Crop Improvement 25(6): 728-741

Naseri F (1991). Oil seeds. Astan Quds Razavi Publications, pp. 816

Pasban-Easlam B (2009). Effects of sowing date on yield and yield components in winter oilseed rape. Journal of Agriculture Knowledge 19(2): 149-162

Rad A H S, Bitarafan Z, Rahmani F, Taherkhani T, Aghdam A M \& Nasresfahani S (2015). Effects of planting date on spring rapeseed (Brassica napus L.) cultivars under different irrigation regimes. Turkish Journal of Field Crops 19(2): 153-157

Rafiei S, Delkhosh B, Shirani-Rad A H \& Zandi P (2011). Effect of sowing dates and irrigation regimes on agronomic traits of Indian mustard in a semi-arid area of Takestan. Journal of American Science 7(10): 721-728

Rahnama A A \& Bakhshandeh A M (2005). Date of planting and direct sowing methods on rapeseed yield and agronomic characteristics in terms of Ahvaz. Journal of Crop Science 8(4): 123-139

Robertson M J, Holland J F \& Bambach R (2004). The response of canola and Indian mustard to sowing date in the grain belt of north-eastern Australia. Australian Journal of Experimental Agriculture 44: 43-52

Shariati S \& Ghazi Shahinzadeh P (2000). Canola. Ministry of Agriculture Jihad Publications, pp. 81

Sharif A E \& Keshta M M (2002). Influence of sowing dates and plant density on growth and yield of canola (Brassica napus) under salt affected soils in Egypt. Scientific Journal of King Faisal University 3(1): 65-76

Siadat S A \& Hemayati S S (2009). Effect of sowing date on yield and yield components of three oilseed rape varieties. Plant Ecophysiology 1: 31-35

Spasibionek S, Krzymański J \& Bartkowiak-Broda I (2003). Mutants of Brassica napus with changed fatty acid composition. pp. 221-223. Processing of $11^{\text {th }}$ International Rapeseed Congress, 6-10 July, Kopenhagen, Dania

Steel R G D \& Torrie J H (1980). Principles and procedures of statistics: A biometrical approach. $2^{\text {nd }}$ ed. Mc GrawHill, New York, pp. 20-90

Sulisbury P, Sang J \& Cawood R (1987). Genetic and environmental factors influencing glucosinolate content in rapeseed in southern Australia, In: Proceedings of the $7^{\text {th }}$ International Rapeseed Congress, 11-14 May, Poland. The plant breeding and acclimatization institute, Poznan, pp. 516-520

Sultan H \& Angadi S V (2016). Effects of planting date on winter canola growth and yield in the southwestern U.S. American Journal of Plant Sciences 7: 201-217

Taylor A J \& Smith C J (1992). Effect of sowing date and seeding rate on yield and yield components of irrigated Canola (Brassica napus L.) grown on a redbrown earth in south-eastern. Australian Journal of Agricultural Research 43: 1929-1941

Turhan H, Kemal M, Egese C \& Kahriman F (2011). Effect of sowing time on grain yield, oil content, and fatty acids in rapeseed (Brassica napus subsp. oleifera). Turkish Journal of Agriculture 35: 225-234

Ul-Hassan F, Ali H, Akhtar Cheema M \& Manaf A (2005). Effects of environmental variation on oil content and fatty acid composition of canola cultivars. Journal of Research (Science) 16: 65-76

Weber J, Bochi V C, Ribeiro C P, Victório A D M \& Emanuelli $T$ (2008). Effect of different cooking methods on the oxidation, proximate and fatty acid composition of silver catfish (Rhamdia quelen) fillets. Food Chemistry 106(1): 140-146

Xia J \& Wishart D S (2016). Using MetaboAnalyst 3.0 for comprehensive metabolomics data analysis current protocols in bioinformatics. Curr Protoc Bioinformatics 55: 1-14

Yang M, Shi L, Xu F S, Lu W \& Wang Y H (2009). Effects of B, Mo, $\mathrm{Zn}$ and their interactions on seed yield of rapeseed (Brassica napus L.). Pedosphere 19(1): 53-59

Yau S K (2007). Winter versus spring sowing of rain-fed safflower in a semi-arid, high-elevation Mediterranean environment. European Journal of Agronomy 26: 249-256

Yin H, Fretté X C, Christensen L P \& Grevsen K (2011). Chitosan oligosaccharides promote the content of polyphenols in Greek oregano (Origanum vulgare ssp. hirtum). Journal of Agricultural and Food Chemistry 60(1): 136-143 